\title{
Article \\ Application of Elicitors at Two Maturation Stages of Vitis vinifera L. cv Monastrell: Changes in Skin Cell Walls
}

\author{
Diego F. Paladines-Quezada *D, Juan D. Moreno-Olivares $\mathbb{D}^{D}$, José I. Fernández-Fernández, \\ Juan A. Bleda-Sánchez (D) and Rocío Gil-Muñoz (D) \\ Murcian Institute of Agrarian and Environmental Research and Development, C/Mayor s/n, La Alberca, \\ 30150 Murcia, Spain; juand.moreno5@carm.es (J.D.M.-O.); josei.fernandez@carm.es (J.I.F.-F.); \\ juanantonio.bleda@carm.es (J.A.B.-S.); mariar.gil2@carm.es (R.G.-M.) \\ * Correspondence: diegof.paladines@carm.es
}

check for

updates

Citation: Paladines-Quezada, D.F.;

Moreno-Olivares, J.D.;

Fernández-Fernández, J.I.; Bleda-Sánchez, J.A.; Gil-Muñoz, R. Application of Elicitors at Two Maturation Stages of Vitis vinifera $\mathrm{L}$. cv Monastrell: Changes in Skin Cell Walls. Chemistry 2022, 4, 98-111.

https://doi.org/10.3390/ chemistry 4010008

Academic Editor: Peter J. Rutledge

Received: 23 December 2021

Accepted: 10 February 2022

Published: 12 February 2022

Publisher's Note: MDPI stays neutral with regard to jurisdictional claims in published maps and institutional affiliations.

Copyright: () 2022 by the authors. Licensee MDPI, Basel, Switzerland. This article is an open access article distributed under the terms and conditions of the Creative Commons Attribution (CC BY) license (https:/ / creativecommons.org/licenses/by/ $4.0 /)$.

\begin{abstract}
The aim of this study was to evaluate whether the application of two pre-harvest relicitors-methyl-jasmonate (MeJ) and benzothiadiazole (BTH) — to Monastrell grapes, at two maturation stages, affected the composition and structure of the skin cell walls (SCWs) to differing extents. This study was conducted in 2016-2017 on Vitis vinifera L. cv Monastrell. A water suspension of MeJ and $\mathrm{BTH}$, and a mixture of both, was applied at veraison and mid-ripening. The composition of the berry SCW was analyzed. Environmental conditions caused substantial changes in SCW composition, especially at high temperatures. Indeed, a reduction of approximately $50 \%$ in the biosynthesis of hemicellulose, proteins and total phenols was observed, accompanied by a slight increase in cellulose and lignin. However, the application of the treatments also caused changes in some SCW constituents: increases in the concentration of phenols, proteins and lignin were observed, especially when the $\mathrm{MeJ}$ and $\mathrm{MeJ}+\mathrm{BTH}$ treatments were applied at veraison. Likewise, a reduction in uronic acids was observed in the MeJ + BTH treatment applied at veraison. These changes in the SCWs could affect their structural characteristics, and therefore influence grape handling in the field and in the winery. Further studies are needed to determine the extent to which MeJ and BTH treatments affect other skin characteristics.
\end{abstract}

Keywords: methyl-jasmonate; benzothiadiazole; veraison; mid-ripening; lignin; cellulose; hemicellulose; proteins; pectins

\section{Introduction}

The importance of phenolic compounds in the agricultural sector is unquestionable because of their role in the adaptation and protection of plants in the face of different types of biotic and abiotic stress [1]. These phenolic compounds are formed through the phenylpropanoid pathway, from the amino acid phenylalanine, and are divided according to their structure in non-flavonoids (i.e., phenolic acids and stilbenes) and flavonoids (i.e., anthocyanins, flavonols, and flavanols) [2]. Anthocyanins are responsible for the grape and wine color, flavanol compounds contribute to wine astringency and bitterness, and flavonols are also responsible for wine bitterness [3]. Moreover, there is a growing interest in polyphenols as bioactive compounds due to their impact on human well-being [4]. In this sense, grapes represent one of the most important sources of polyphenols for people, whether consumed as fresh fruit or in red wines [5]. Therefore, several of the viticultural and enological strategies currently employed are aimed at increasing the concentration of polyphenols in grapes and wines, while remaining environmentally friendly. One of these strategies consists of the exogenous application of products called "elicitors", which trigger a cascade of physiological events such as changes in membrane potential and ion fluxes, the production of reactive oxygen species (ROS) [6], or the activation of genes related to the synthesis of secondary metabolites [7]. Ultimately, plant defense responses involve 
the strengthening of cell walls (CWs) and the production of antimicrobial compounds, including phytoalexins and pathogenesis-related proteins, which, together, play a key role in pathogen containment [8]. This suggests that elicitation may be one of the most effective ways to enhance the production of bioactive compounds, such as cyanogenic glycosides, glucosinolates [9], alkaloids, phenols, or terpenes [10], in addition to defending the plant against pathogen attacks.

Among these elicitors, methyl jasmonate (MeJ) and benzothiadiazole (BTH) have been used to increase the phenolic content of fruits, particularly grapes, while also being considered useful as agrochemicals to improve resistance against plant pathogens [11-15]. Jasmonic acid and MeJ are naturally occurring plant growth regulators that modulate chlorophyll degradation and anthocyanin biosynthesis. MeJ has been mainly implicated as a mediator in the plant responses triggered by wounding and insect feeding, and is involved in pathogen resistance [16]. BTH is a synthetic functional analog of the plant endogenous hormone-like compound salicylic acid, which induces defense genes leading to systemic acquired resistance (SAR) and an increase in phenolic production [17]. Taking into account that MeJ is a naturally occurring plant metabolite and BTH is seen to be completely translocated and degraded in plant tissues, and therefore no persistence or residue problems are expected [17], both products could be considered an interesting strategy to protect the vine, as an alternative or complement to fungicide treatments, increasing, at the same time, the phenolic content of the grapes [13].

However, most studies carried out involve treatments at the beginning of veraison, a relatively short period during which it is not always possible to apply the necessary treatments, meaning that using elicitors in large areas of vineyards or in unfavorable environmental conditions may be complicated. For this reason, in a recent study, we evaluated the application of $\mathrm{MeJ}$ and $\mathrm{BTH}$ at two different times during the ripening period of Monastrell grapes [18]. The results indicated that the most suitable period for the application of $\mathrm{MeJ}, \mathrm{BTH}$, and $\mathrm{MeJ}+\mathrm{BTH}$ was at mid-ripening, since the grapes showed a greater accumulation of anthocyanins at harvest. However, the increase in the anthocyanin content of grapes was not reflected in all the wines, which may have been due to the reinforcement of the skin cell wall (SCW) following the application of the elicitors.

From an oenological point of view, SCWs are relevant because of their involvement in the extractability of phenolic and aromatic compounds in grapes, since they represent a diffusion barrier for these compounds during the vinification stage [19], and because SCWs are the main source of pectic polysaccharides in wine [20]. In addition, several studies support the hypothesis that reduced tannin extraction from grape into wine is the result of tannin and cell wall interactions. Tannin-cell wall binding occurs primarily through hydrogen bonding and hydrophobic interactions between tannins and polysaccharides, where the strength of these interactions is influenced by tannin and polysaccharide composition, content, and structure. While changes in cell walls during grape berry development may increase their tannin-binding capacity, the structure of tannins could also influence the affinity for cell wall polysaccharides [21]. Therefore, knowledge of their composition, structure and functions in wine grapes, both in normal conditions and after chemical induction, is necessary. Such knowledge would allow appropriate decisions to be taken, whether in the field or during the maceration process, and enable a greater proportion of these beneficial compounds to be extracted.

Based on the results of our previous assay, and taking into consideration that the last event after a stimulus is the strengthening of the cell walls [8], we hypothesized that the application of elicitors at veraison would have a greater effect on the structure and composition of cell wall components than application at mid-ripening. This would help explain why an increase in anthocyanins in grapes after the application of MeJ and BTH was not evident in all the wines of our trial. The present paper aims to evaluate whether the application of two pre-harvest elicitors-methyl jasmonate (MeJ) and benzothiadiazole (BTH) - to Monastrell grapes, during two maturation stages, affects the composition and structure of the SCW to the same extent. 


\section{Materials and Methods}

\subsection{Experimental Design}

The experiment was carried out over two consecutive years (2016-2017) in Jumilla, Murcia (southeastern Spain) $\left(38^{\circ} 22^{\prime} 58.5^{\prime \prime} \mathrm{N}, 1^{\circ} 26^{\prime} 30.8^{\prime \prime} \mathrm{W}\right.$, elevation $380 \mathrm{~m}$ ). Total precipitation and average temperature during the grape ripening period in 2016 were $2.6 \mathrm{~mm}$ and $24.9^{\circ} \mathrm{C}$, and $54.6 \mathrm{~mm}$ and $25.5^{\circ} \mathrm{C}$ in 2017 [22]. The study was performed on 14-year-old Vitis vinifera cv. Monastrell (syn. Mourvedre) red wine grapevines, grafted onto 1103-Paulsen (clone 249) rootstock, and trained in a bilateral cordon training system trellised to a three wire. Vine rows were arranged N-NW to S-SE with between-row and within-row spacing of $3 \times 1.25 \mathrm{~m}$.

The experiments were conducted in a randomized block design, in which all treatments were applied to three replicates, using 10 vines for each replication. The protocol used to apply the different treatments, as well as the doses, has been described previously [18] Plants (leaves and clusters) were sprayed with a water suspension of two elicitors: MeJ at a concentration of $10 \mathrm{mM}$; BTH at a concentration of $0.3 \mathrm{mM}$, or a mixture of both (at the same concentration of each component). Aqueous solutions (200 mL per plant) were prepared with Tween 80 as wetting agent $(0.1 \% v / v)$. Control plants were sprayed with aqueous solution of Tween 80 alone. The treatments were applied at two different stages of berry development (Figure 1): at veraison and at mid-ripening (3 weeks after veraison, as the Monastrell ripening period in this area lasts about 6 weeks). Based on the results of previous works with this and other grape cultivars [13], a second application was performed for all the treatments 7 days after the first, in order to maximize polyphenol accumulation. When the grapes reached technological maturity (maximum sugar/acidity ratio, as determined from the control grapes), they were harvested and transported in boxes to the winery for physicochemical analysis and vinification. Representative samples of grapes were taken from each treatment (ca. 800 g.) and frozen at $-80{ }^{\circ} \mathrm{C}$ until further analysis.
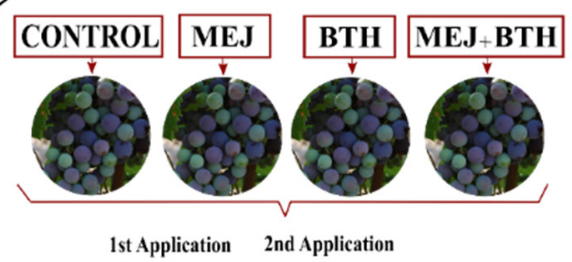

$200 \mathrm{~mL} /$ vine $\quad 200 \mathrm{~mL} /$ vine

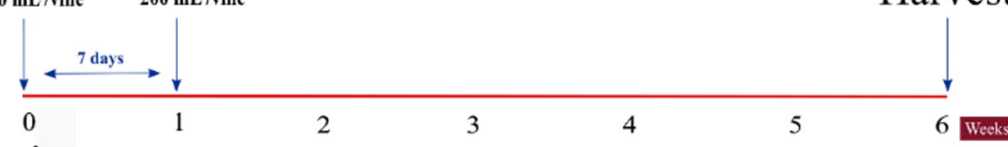

Veraison

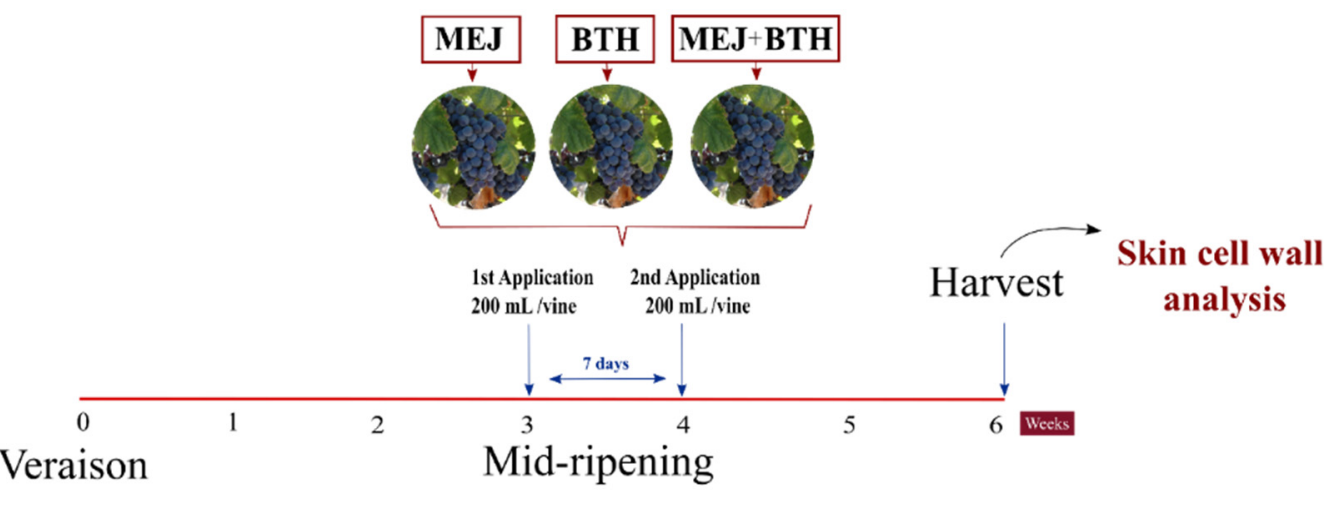

Figure 1. Application of treatments at two stages of ripening of Monastrell grapes. 


\subsection{Reagents and Standards}

Both solvents (acetone, ethanol) were of HPLC quality, and all chemicals were of analytical grade (>99\%). Water was of Milli-Q quality. BTH ([benzo-(1, 2, 3)-thiadiazole-7carbothioic acid S-methyl ester]); MeJ (methyl jasmonate); Tween 80; 3, 5-dimethylphenol, were from Sigma Aldrich (St. Louis, MO, USA). For glucose determination, an enzymatic analysis kit from R-biopharm (Darmstadt, Germany) was used. As standards, pure galacturonic acid and gallic acid were purchased from Sigma Aldrich (St. Louis, MO, USA) and Bovine serum albumin (BSA) from J.T. Baker (Deventer, The Netherlands).

\subsection{Isolation of Skin Cell Wall (SCW)}

SCWs were isolated following the method described by de Vries et al. (1984) [23], which is considered the most suitable method for grapes [24]. For this, $10 \mathrm{~g}$ of grape tissue was suspended in $50 \mathrm{~mL}$ of boiling water for $5 \mathrm{~min}$ and then homogenized. The mixture was homogenized and centrifuged $\left(11,000 \mathrm{rpm} ; 25^{\circ} \mathrm{C} ; 15 \mathrm{~min}\right)$. The supernatant was removed, and the solid residue was resuspended in $70 \%$ ethanol for 30 min and kept under constant stirring at $40-50{ }^{\circ} \mathrm{C}$. The extraction procedure with $70 \%$ ethanol was repeated until the sugars were eliminated (about 9-10 times). The presence of sugars was determined qualitatively in the supernatant by the method described by Dubois et al. (1956) [25]. The residue obtained was washed once with absolute ethanol and twice with acetone, and finally dried overnight under an air stream at room temperature.

\subsection{Skin Cell Wall (SCW) Composition}

The SCW composition was analyzed according to Castro-López et al. (2016) [26] (Figure 2). Total glucose was determined using a kit for glucose enzymatic analysis after pre-treatment $\left(30^{\circ} \mathrm{C}, 1 \mathrm{~h}\right)$ with aqueous $72 \%$ sulfuric acid, followed by hydrolysis using $1 \mathrm{M}$ sulfuric acid $\left(100{ }^{\circ} \mathrm{C}, 3 \mathrm{~h}\right)$ to determine non-cellulosic glucose. Cellulosic glucose was obtained by difference between the total glucose and non-cellulosic glucose content. Uronic acids were determined in the sulfuric acid cell wall hydrosylate by the colorimetric 3,5dimethylphenol assay after pre-treating the cell walls $\left(30^{\circ} \mathrm{C}, 1 \mathrm{~h}\right)$ with aqueous $72 \%$ sulfuric acid, followed by hydrolysis with $1 \mathrm{M}$ sulfuric acid $\left(100^{\circ} \mathrm{C}, 3 \mathrm{~h}\right)$ [27]. Pure galacturonic acid was used as standard, and Klason lignin was determined gravimetrically after sulfuric acid hydrolysis [28], expressing the lignin content as $\mathrm{mg} g-1$ of cell wall. The proteins and total phenolic compound content of the cell wall material was determined after extraction with $1 \mathrm{M} \mathrm{NaOH}\left(100{ }^{\circ} \mathrm{C}, 10 \mathrm{~min}\right)$ by the colorimetric Coomassie Brilliant Blue assay and by the colorimetric Folin-Ciocalteau reagent assay, respectively. Bovine serum albumin (BSA) fraction $\mathrm{V}$ and pure gallic acid were used as standards, respectively. 


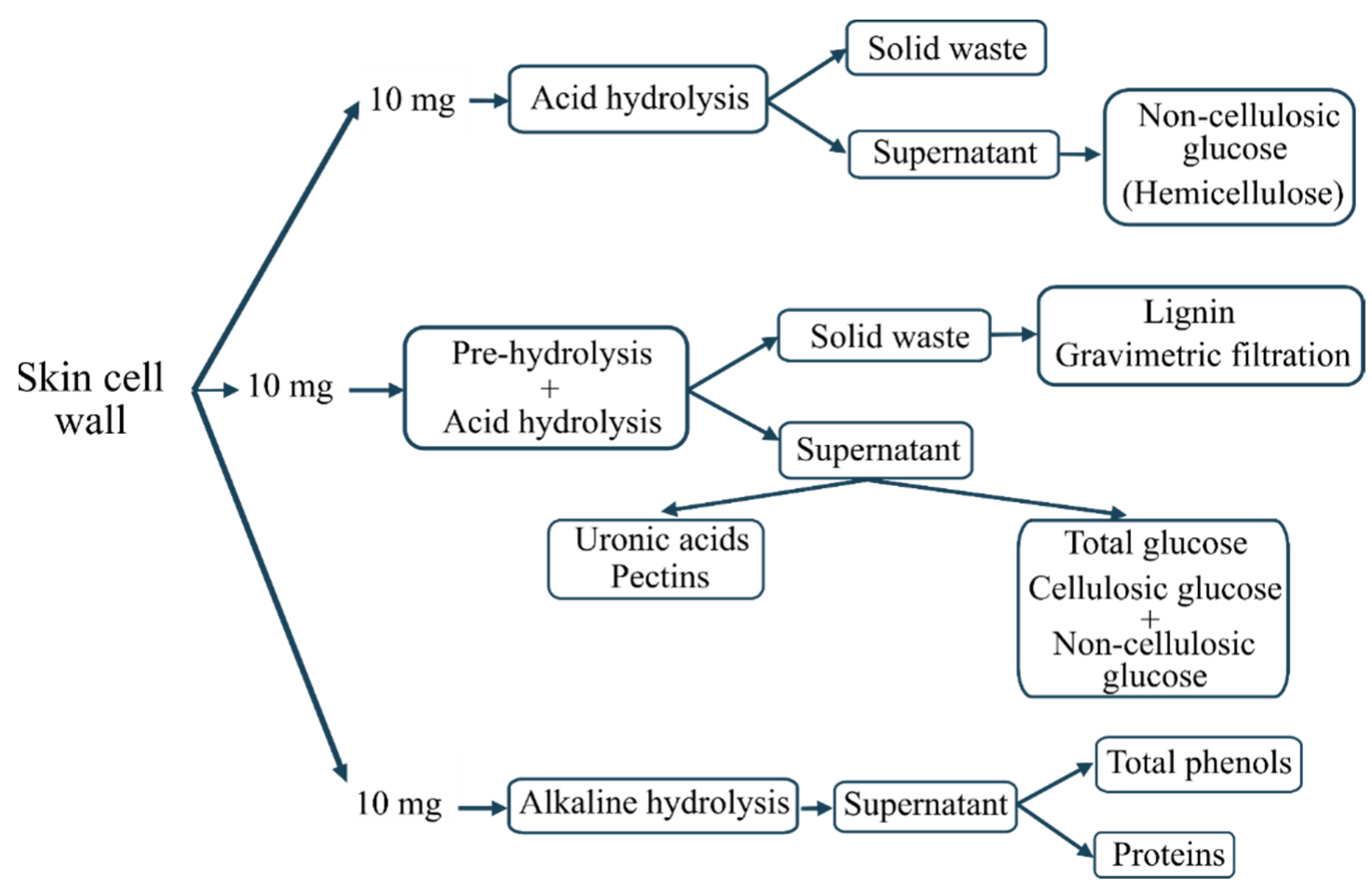

Figure 2. Skin cell wall analysis protocol.

\section{Results and Discussion}

\subsection{Isolation of Skin Cell Wall (SCW)}

The results indicated that the average fresh skin weight for the 2016 and 2017 seasons was around $7.6 \mathrm{~g} / 100 \mathrm{~g}$ of grapes (Table 1), i.e., there were no significant differences between seasons. This parameter (skin weight) is positively correlated with berry weight, but negatively correlated with skin percentage, due to the variation of the volume/surface ratio [29]. In this regard, berry weights during 2017 were slightly higher than those of 2016 (data not shown); apparently, this increase did not affect fresh skin weight to a greater extent. In addition, none of the elicitor applied treatments influenced the amount of fresh skin obtained.

With respect to the amount of SCW isolated from fresh grape skins, they were slightly higher than those found by other authors [24,30], who also analyzed Monastrell grapes from the same growing area.

On the other hand, our results revealed that the SCW isolated in 2016 was $117 \mathrm{mg} / \mathrm{g}$ as an average value, which was much higher than the SCW isolated in 2017 (95 mg/g). These differences could be attributed to the different climatic conditions experienced in the study vintages [31], especially between the months of July and August 2017, where the plants endured a greater number of days with temperatures above $30{ }^{\circ} \mathrm{C}$, in addition to the number of heavy rainfall days before harvest, which may have led to maladjustments in the physiology of the grapes. Regarding the results obtained in 2016 and 2017, grapes treated at veraison showed slightly lower SCW values than grapes treated at mid-ripening, but this was not statistically significant. Furthermore, no differences were detected between the different treatments and the control grapes. 
Table 1. Characteristics of grapes at harvest time during two seasons (2016-2017).

\begin{tabular}{|c|c|c|c|c|c|c|c|c|}
\hline \multirow{2}{*}{ Year } & \multirow{2}{*}{ Parameter } & \multirow{2}{*}{ Control } & \multicolumn{3}{|c|}{ Veraison } & \multicolumn{3}{|c|}{ Mid-Ripening } \\
\hline & & & MeJ & BTH & MeJ + BTH & MeJ & BTH & MeJ + BTH \\
\hline 2016 & $\begin{array}{c}\text { Fresh skin (g) } \\
\text { SCW (mg/g fresh skin) }\end{array}$ & $\begin{array}{l}7.6 \pm 1.1 \mathrm{a} \\
116 \pm 6 \mathrm{ab}\end{array}$ & $\begin{aligned} 8.1 & \pm 0.1 \mathrm{a} \\
112 & \pm 10 \mathrm{ab}\end{aligned}$ & $\begin{array}{l}7.9 \pm 0.1 \mathrm{a} \\
106 \pm 8 \mathrm{a}\end{array}$ & $\begin{array}{l}7.7 \pm 0.3 \mathrm{a} \\
115 \pm 9 \mathrm{ab}\end{array}$ & $\begin{array}{l}7.0 \pm 0.6 \mathrm{a} \\
127 \pm 7 \mathrm{~b}\end{array}$ & $\begin{array}{l}7.2 \pm 0.4 \mathrm{a} \\
120 \pm 8 \mathrm{ab}\end{array}$ & $\begin{array}{c}7.1 \pm 0.4 \mathrm{a} \\
132 \pm 7 \mathrm{~b}\end{array}$ \\
\hline 2017 & $\begin{array}{c}\text { Fresh skin }(\mathrm{g}) \\
\mathrm{SCW}(\mathrm{mg} / \mathrm{g} \text { fresh skin) }\end{array}$ & $\begin{array}{l}7.4 \pm 1 \mathrm{a} \\
88 \pm 7 \mathrm{a}\end{array}$ & $\begin{array}{l}7.4 \pm 0.7 \mathrm{a} \\
94 \pm 6 \mathrm{a}\end{array}$ & $\begin{array}{l}7.4 \pm 0.9 a \\
93 \pm 6 a\end{array}$ & $\begin{array}{l}8.1 \pm 0.6 \mathrm{a} \\
94 \pm 6 \mathrm{a}\end{array}$ & $\begin{array}{l}8.3 \pm 0.8 \mathrm{a} \\
100 \pm 6 \mathrm{a}\end{array}$ & $\begin{array}{l}7.6 \pm 0.8 \mathrm{a} \\
102 \pm 6 \mathrm{a}\end{array}$ & $\begin{array}{l}7.7 \pm 0.6 \mathrm{a} \\
95 \pm 4 \mathrm{a}\end{array}$ \\
\hline
\end{tabular}

Abbreviations: MeJ, methyl jasmonate; BTH, benzothiadiazole. Data represent means \pm standard deviation Different letters in the same row indicate significant differences according to Duncan's test $(p<0.05)$.

Although there were no significant differences in the amount of SCW due to the application of elicitors, knowledge of this parameter can help to make decisions at the enological level, since several studies have shown the correlation between the amount of cell wall found in grapes and some of the processes that occur during winemaking. Thus, Ortega-Regules et al. (2006) [32] found that the Monastrell variety showed a higher amount of SCW, and that this parameter was directly correlated with the poor polyphenol extraction rates compared to the rates obtained in the Cabernet Sauvignon, Syrah and Merlot varieties. In the same line, Hernández-Hierro et al. (2014) [33] observed that the amount SCW from Tempranillo grapes was negatively correlated with anthocyanin extraction, while SCW components such as cellulose, rhamnogalacturonans and polyphenols were positively correlated with the same, suggesting that the amount of SCW is a crucial factor for anthocyanin extraction, and that the qualitative composition of the SCW also plays an important role.

\subsection{Carbohydrate Composition of Cell Walls (Cellulosic Glucose, Non-Cellulosic Glucose and Uronic Acids)}

\subsubsection{Cellulosic Glucose (Cellulose)}

The results showed that cellulose accounted for about $15 \%$ of the SCW during the two campaigns (Figure 3A,B). In addition, during both campaigns, the BTH treatment applied at mid-ripening induced a higher degree of cellulose biosynthesis in the SCWs of Monastrell grapes. This could directly affect the plant defenses against potentially pathogenic organisms, or affect the extraction of phenolic compounds during the maceration process, since cellulose is an essential component in cell maintenance and tissue structure, due to the three-dimensional network of microfibrils it forms in the $\mathrm{CW}$, conferring mechanical resistance to the tissues by acting as a physical barrier [34].

\subsubsection{Non-Cellulosic Glucose (Hemicellulose)}

With respect to SCW hemicelluloses concentration, the results showed a marked difference between the two campaigns, (Figure 3C,D), the samples analyzed in 2016 having a higher hemicelluloses concentration than those analyzed in 2017.

The results obtained for the two seasons indicated that MeJ and MeJ + BTH treatments applied at veraison caused a decrease in the hemicellulose concentration of the SCWs of Monastrell grapes. Although hemicellulose was the structural polysaccharide with the lowest concentration in Monastrell SCW (2-4\%) (compared to $15 \%$ cellulose and $30 \%$ pectin), a decrease in its concentration, either due to environmental factors or the application of elicitors, would also affect the physicochemical characteristics of SCW, since it would interact to a lesser extent with cellulose microfibrils, losing the ability to form a large lattice. As with cellulose fibrils, hemicelluloses are also essential for maintaining the organized structure of CWs [34]. 


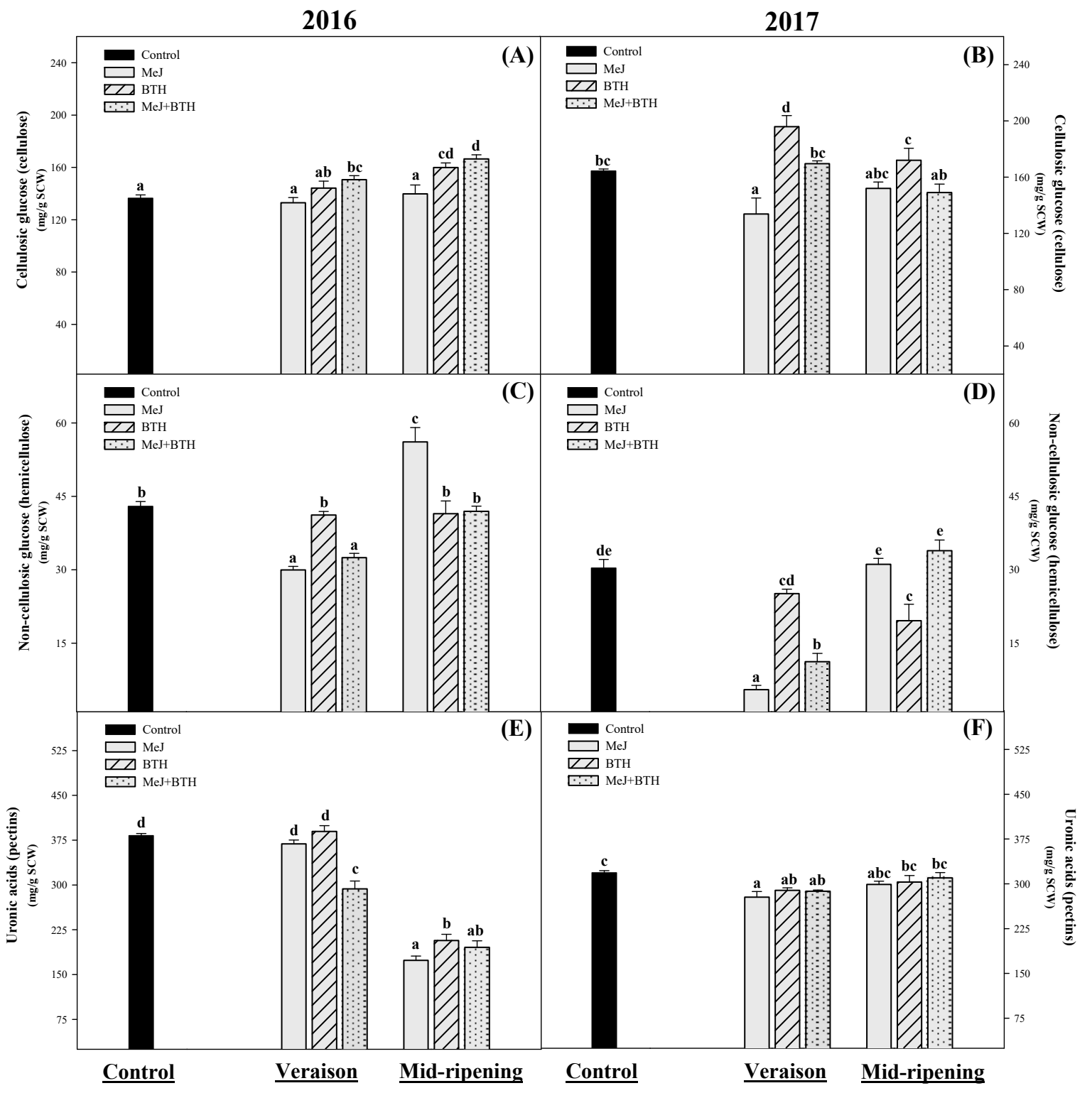

Figure 3. Concentration of cellulosic glucose (A,B), non-cellulosic glucose $(\mathbf{C}, \mathbf{D})$ and uronic acids (E,F) of Monastrell grape skin cell walls, during two seasons (2016 and 2017). Different letters indicate significant differences according to Duncan's test $(p<0.05)$. Abbreviations: MeJ, methyl jasmonate; BTH, benzothiadiazole.

\subsubsection{Uronic Acids (Pectins)}

These are the main components of pectic polysaccharides, which act as cementing substances and contribute to intracellular adhesion and cell wall strength [35], and are mainly present in the primary wall [36]. In this study, the analyses carried out during the two campaigns (Figure 3E,F) showed that pectins were the principal structural polysaccharides in Monastrell SCWs, with an average concentration of approximately $30 \%$.

Regarding the effect of the treatments, MeJ + BTH applied at veraison was the only treatment that caused a decrease in pectin concentration in the two seasons studied. However, the general trend after elicitor application was a reduction in pectic polysaccharides in the SCWs of berries. This effect could negatively affect the defense mechanisms of the grapevine, since the $\mathrm{CW}$, in addition to acting as a physical barrier against pathogenic organisms, also acts as a source of biologically active molecules such as oligosaccharins [34]. These oligosaccharins are biologically active fragments resulting from $\mathrm{CW}$ pectin degradation that have some physiological and developmental effects such as: (1) stimulation 
of phytoalexin synthesis; (2) oxidative burst; (3) ethylene synthesis; (4) membrane depolarization; (5) induced synthesis of pathogenesis-related proteins, in addition to local and systemic wound signals, among others [37]. Likewise, another negative effects of the decrease in the concentration of pectic derivatives in grape SCW could be their reduced availability for release during the maceration processes, leading to wines with a more astringent sensation. This is the case of Type II rhamnogalacturonans (RG-II), one of the most abundant pectic polysaccharides in wine [38], which is present in grape from the beginning of vinification, meaning that it is partially released throughout the maceration period [39]. RG-II have been correlated with organoleptic properties of wine, as they are able to soften the sensation of astringency [40].

\subsection{Lignin, Proteins and Total Phenols}

\subsubsection{Lignin}

In our study, lignin found in the samples represented between $40-45 \%$ of the composition of SCWs (Figure 4A,B), being the second most abundant component after structural polysaccharides (cellulose, hemicellulose and pectins).

It was seen that during both seasons, $\mathrm{MeJ}$ and $\mathrm{MeJ}+\mathrm{BTH}$ treatments applied at veraison increased the concentration of lignin in the SCWs of Monastrell grapes. It is known that lignin deposition or lignification in the secondary CW occurs in the later stages, when the cell has stopped dividing and expanding, although its biosynthesis can also be induced by biotic and abiotic stress conditions [41,42]; hence, the aforementioned treatments may have induced its biosynthesis. However, this was the opposite behavior to that found in the case of hemicellulose (Figure 3C,D), whose concentration decreased after the application of MeJ and $\mathrm{MeJ}+\mathrm{BTH}$ during veraison. In relation to this, lignin deposition between the cellulose microfibrils may increase the wall thickness, conferring greater mechanical resistance to the cellulose [35] and, given its hydrophobic character, its presence in CWs forces water to move, increasing strength and stiffness [34]. In this way, lignin has also been correlated with plant defense mechanisms [43]. However, although the level of hemicellulose was low in the SCW (2-4\%), any decrease in its concentration could affect structural strength, since cross-linking between structural lignin and hemicellulose during lignification would be reduced [44].

\subsubsection{Proteins}

CW structural proteins are other compounds that have been correlated with plant defense mechanisms, as they are expressed in response to various plant stress and developmental conditions $[45,46]$.

In our assay, the SCWs from grapes analyzed in 2016 had a two-fold higher protein concentration than the SCWs from the 2017 grapes (Figure 4C,D), underlining the fact that structural protein synthesis was also highly sensitive to environmental conditions.

With regards to the effect of the elicitors on the proteins, the results obtained for the two seasons indicate that the MeJ treatment applied during veraison was the only one that increased the protein concentration of the SCWs of Monastrell grapes, although it should be noted that there was a slight tendency for the protein concentration to increase after the application of most of the elicitors. In this regard, it should be noted that the abundance of these structural proteins varies greatly depending on cell type, maturation and prior stimulation such as injury, attack by pathogens or treatment with elicitors, which increase the expression of genes encoding many of these proteins [47]. However, in addition to this increase in gene expression, it has been observed that proline-rich structural proteins quickly become insoluble after injury or treatment with elicitors, which has been associated with an oxidative burst and with mechanisms that increase mechanical rigidity of the CW. This is corroborated by in vitro extraction studies, which showed that newly secreted structural proteins are relatively soluble, but become more and more insoluble during cell maturation or in response to injury. However, the biochemical nature of the insolubilization process is uncertain [47]. 


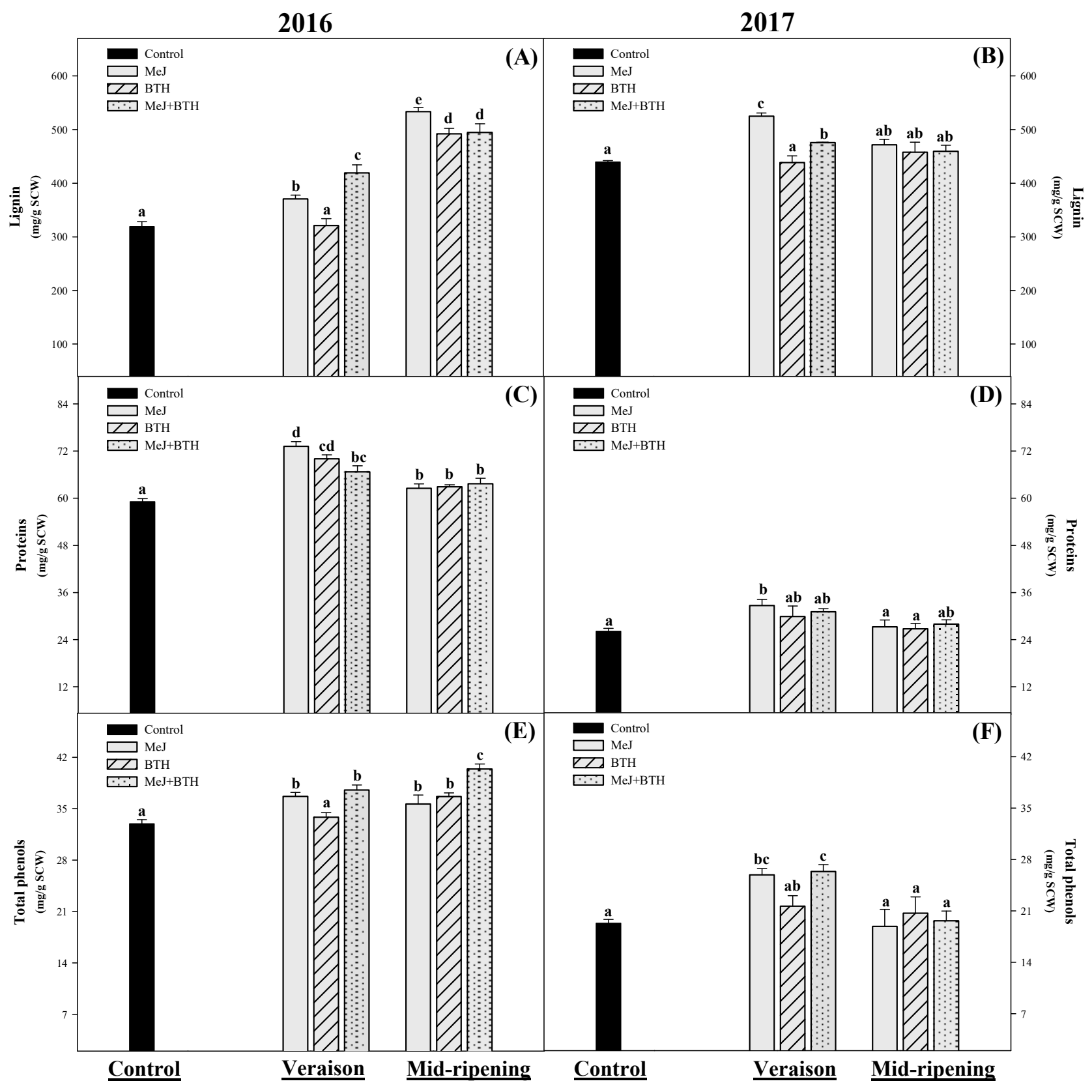

Figure 4. Concentration of lignin (A,B), proteins (C,D) and total phenols (E,F) of Monastrell grape skin cell walls, during two seasons (2016 and 2017). Different letters indicate significant differences according to Duncan's test $(p<0.05)$. Abbreviations: MeJ, methyl jasmonate; BTH, benzothiadiazole.

\subsubsection{Total Phenols}

In grape skins, phenols are bound to polysaccharides by hydrophobic interactions and hydrogen bonds [48], and form part of the primary and secondary CW [49]. The main phenols of CWs are ferulic acid and p-coumaric, whose bonds seem to limit the spread of the $\mathrm{CW}$, and could play an important role in resistance to fungal pathogens [50].

The environmental conditions of the experiment area also had a great influence on the concentration of total phenols that make up the SCW, since all the samples analyzed in 2016 presented a higher concentration than the samples of 2017 (Figure 4E,F).

As with lignin, the MeJ and MeJ + BTH treatments applied at veraison during both seasons, resulted in an increase in the concentration of total phenols in the SCW. Such an increase might improve the defense mechanisms of Monastrell berries against fungal attack, since it has been observed that when plant cells are damaged or treated with elicitor 
molecules of small molecular mass, they activate defense responses that give rise to the production of a high concentration of $\mathrm{H}_{2} \mathrm{O}_{2}$, superoxide radicals and other ROS in the $\mathrm{CW}$. This oxidative burst appears to be part of the defensive response against invasion by pathogens. ROS can directly attack pathogenic organisms, and can indirectly stop further invasion by them by causing rapid reticulation or the cross-linking of $\mathrm{CW}$ phenolic compounds [51].

The variations in SCW components following the application of the treatments during veraison were more pronounced than when applied at mid-ripening, which would have given more time for any reactions to take place in the biosynthetic pathways for the generation and assembly of the structural components of the SCW. This may increase resistance to fungal attacks but may make the extraction of polyphenols from the skin during the maceration process more difficult.

\subsection{Multivariate Analysis}

A multivariate analysis was carried out (Table 2) to obtain an overview of the influence of the environmental conditions in each campaign, the type of treatment used, as well as the moment of its application on the components of the SCWs of Monastrell grapes.

In this way, it was possible to confirm that the environmental conditions prevailing in each of the campaigns was decisive in the composition of the SCWs of the grapes. This is particularly true of the adverse conditions suffered during 2017, when temperatures above $30{ }^{\circ} \mathrm{C}$ lasted for longer periods compared with 2016 [18], advancing veraison by approximately 15 days. These extreme conditions during 2017 may have been responsible for the observed decrease of approximately $50 \%$ in hemicellulose, proteins and total phenols in the SCW; by contrast, cellulose and lignin levels increased. However, pectins were not affected by the prevailing weather conditions. In this regard, a preliminary study also described notable differences in the concentrations of the SCW components of Monastrell, Merlot and Cabernet Sauvignon varieties in different seasons, with the exception of pectin and cellulose, whose concentrations were not affected [52]. Likewise, in a study carried out in the Syrah variety, Garrido-Bañuelos et al. (2019) [31] also observed marked differences in the concentration of the SCW components during two consecutive vintages, differences which were attributed to higher temperatures in one of the trial vintages, but, unlike in our study, these authors also found marked differences in the concentration of pectins.

Regarding the time of application of the treatments (veraison or mid-ripening), this factor affected the composition of the $\mathrm{CW}$ in a heterogeneous way. It was found that the grapes treated mid-ripening had a higher concentration of hemicellulose and lignin, and a lower concentration of pectins in the SCW, compared to the grapes treated at veraison. In this respect, we have found insufficient information in the literature about the response of cell walls to the application of elicitors at different stages of berry development to enable a comparison with our results.

Regarding the type of treatment used and its influence on each of the SCW components, we observed that the treatment with BTH was the only one that increased the cellulose concentration, while all the treatments (MeJ, BTH and MeJ + BTH) caused a decrease in the concentration of pectins and contributed to a greater accumulation of lignin. In the case of hemicellulose, proteins and total phenols, there were no significant differences between the grapes treated with elicitors and the control grapes. Part of these results can be corroborated with those obtained in a previous study [52], in which MeJ and BTH, applied at the beginning of veraison, led to a decrease in the pectin concentration of the SCW in Cabernet Sauvignon grapes, suggesting that the response to the application of these treatments will depend on the variety. 
Table 2. Multivariate analysis of SCW components of Monastrell grapes, treated with MeJ, BTH and $\mathrm{MeJ}+\mathrm{BTH}$, at two different ripening stages: veraison and mid-ripening, during the 2016 and 2017 seasons.

\begin{tabular}{|c|c|c|c|c|c|c|c|}
\hline \multirow[b]{2}{*}{ Factor } & & \multicolumn{6}{|c|}{ Cell Wall Components } \\
\hline & & $\begin{array}{l}\text { Cellulosic } \\
\text { Glucose } \\
\text { (Cellulose) }\end{array}$ & $\begin{array}{c}\text { Non-Cellulosic } \\
\text { Glucose } \\
\text { (Hemicellulose) }\end{array}$ & $\begin{array}{l}\text { Uronic Acids } \\
\text { (Pectins) }\end{array}$ & Lignin & Proteins & Total Phenols \\
\hline Year & 2016 & $146 \pm 14 \mathrm{a}$ & $40 \pm 8 b$ & $295 \pm 89 a$ & $414 \pm 84 \mathrm{a}$ & $66 \pm 5 b$ & $36 \pm 2 b$ \\
\hline$(\mathrm{Y})$ & 2017 & $162 \pm 22 b$ & $22 \pm 11 \mathrm{a}$ & $298 \pm 18$ a & $467 \pm 33 b$ & $29 \pm 4 \mathrm{a}$ & $22 \pm 4 \mathrm{a}$ \\
\hline \multirow{3}{*}{ Time of Application (TA) } & Veraison & $153 \pm 23 a$ & $27 \pm 13 a$ & $326 \pm 46 b$ & $414 \pm 71 \mathrm{a}$ & $49 \pm 20 a$ & $29 \pm 7 a$ \\
\hline & Mid-ripening & $156 \pm 15 a$ & $36 \pm 12 b$ & $254 \pm 59 a$ & $482 \pm 34 b$ & $44 \pm 18 \mathrm{a}$ & $28 \pm 10 a$ \\
\hline & Control & $150 \pm 15 a b$ & $37 \pm 7 \mathrm{a}$ & $351 \pm+35 b$ & $379 \pm 66 \mathrm{a}$ & $43 \pm 18 \mathrm{a}$ & $26 \pm 7 \mathrm{a}$ \\
\hline \multirow{3}{*}{$\begin{array}{l}\text { Treatments } \\
(\mathrm{T})\end{array}$} & MeJ & $139 \pm 15 \mathrm{a}$ & $29 \pm 18 \mathrm{a}$ & $287 \pm 70 \mathrm{a}$ & $471 \pm 69 \mathrm{~b}$ & $48 \pm 21 \mathrm{a}$ & $29 \pm 8 \mathrm{a}$ \\
\hline & BTH & $168 \pm 23 c$ & $32 \pm 11 \mathrm{a}$ & $297 \pm 69 a$ & $427 \pm 71 \mathrm{ab}$ & $47 \pm 20 \mathrm{a}$ & $28 \pm 8 \mathrm{a}$ \\
\hline & $\begin{array}{c}\mathrm{MeJ}+\mathrm{BTH} \\
\mathrm{Y} \times \mathrm{T}\end{array}$ & $\begin{array}{c}158 \pm 12 b c \\
n s\end{array}$ & $\begin{array}{c}29 \pm 12 \mathrm{a} \\
*(3 \%)\end{array}$ & $\begin{array}{c}277 \pm 46 \mathrm{a} \\
*(12 \%)\end{array}$ & $\begin{array}{c}460 \pm 35 b \\
n s\end{array}$ & $\begin{array}{c}46 \pm 19 a \\
n s\end{array}$ & $\begin{array}{c}30 \pm 9 a \\
n s\end{array}$ \\
\hline \multirow{3}{*}{ Interactions } & $\mathrm{Y} \times \mathrm{TA}$ & ns & ns & $* * *(29 \%)$ & $* * *(17 \%)$ & ns & $* *(2 \%)$ \\
\hline & $\mathrm{T} \times \mathrm{TA}$ & ns & $* * *(21 \%)$ & $*(9 \%)$ & $* *(7 \%)$ & $* *(1 \%)$ & ns \\
\hline & $\mathrm{Y} \times \mathrm{T} \times \mathrm{TA}$ & $*(8 \%)$ & $*(2 \%)$ & $*(12 \%)$ & $*(8 \%)$ & ns & ns \\
\hline
\end{tabular}

Abbreviations: MeJ: Methyl jasmonate; BTH: Benzothiadiazole. All individual cell wall components are expressed in $\mathrm{mg} \mathrm{g}^{-1}$ of SCW. Total phenols ( $\mathrm{mg}$ gallic acid), proteins ( $\mathrm{mg}$ bovine serum albumin), lignin ( $\mathrm{mg}$ ), uronic acids (mg galacturonic acid), cellulosic and non-cellulosic glucose (mg glucose). Different letters in the same column and factor indicate significant differences according to Duncan's test $(p<0.05)$. Separation by multiple range test at $99.9 \%{ }^{* * *}(p<0.001), 99 \%{ }^{* *}(p<0.01)$ and $95 \%{ }^{*}(p<0.05)$ and ns not significant. Superscript in interactions indicates percentage of variance.

Regarding the interactions between the different factors, it was observed that pectin presented significant differences in all the interactions, the most significant being the interaction Year $\times$ Time of Application $(\mathrm{Y} \times \mathrm{TA})(29 \%$ of the variance). Lignin was another of the components that showed significant differences in all interactions, except for the interaction Year $\times$ Treatment $(\mathrm{Y} \times \mathrm{T})$ and, as in the case of pectin, the most significant interaction was $Y \times$ TA ( $17 \%$ of the variance). Similarly, hemicellulose presented significant differences in almost all the interactions, although, unlike pectin and lignin, it showed no differences in the $Y \times$ TA interaction, its most significant interaction ( $21 \%$ of the variance) being in the Treatment $\times$ Time of Application $(\mathrm{T} \times \mathrm{TA})$ interaction. This general analysis showed that these three components of SCWs (pectin, lignin and hemicellulose) were the most susceptible to changes in the interactions of the three factors studied.

\section{Conclusions}

Environmental conditions caused substantial changes in SCW composition, especially at high temperatures. Indeed, a reduction of approximately $50 \%$ in the biosynthesis of hemicellulose, proteins and total phenols was observed, accompanied by a slight increase in cellulose and lignin. However, the application of the treatments also caused changes in some SCW constituents, since increases in the concentration of phenols, proteins and lignin were observed, especially when the $\mathrm{MeJ}$ and $\mathrm{MeJ}+\mathrm{BTH}$ treatments were applied at veraison. Likewise, a reduction of uronic acids was observed in the MeJ + BTH treatment applied at veraison. These changes in the SCWs could affect their structural characteristics, and therefore influence grape handling in the field and in the winery. Further studies are needed to determine the extent to which MeJ and BTH treatments affect other skin characteristics.

Author Contributions: Conceptualization, D.F.P.-Q.; data curation, D.F.P.-Q. and J.D.M.-O.; formal analysis, D.F.P.-Q.; funding acquisition, R.G.-M.; investigation, D.F.P.-Q., J.D.M.-O., J.I.F.-F. and J.A.B.S.; methodology, D.F.P.-Q., J.D.M.-O., J.I.F.-F., J.A.B.-S. and R.G.-M.; project administration, R.G.-M.; resources, J.A.B.-S. and R.G.-M.; writing-original draft, D.F.P.-Q.; writing-review and editing, D.F.P.-Q. and R.G.-M. All authors have read and agreed to the published version of the manuscript.

Funding: This research was funded by INIA (Instituto Nacional de Investigación y Tecnología Agraria y Alimentaria), grant number: RTA2013-00053-C03-02 and "IMIDA (Instituto Murciano de Investigación y Desarrollo Agrario y Medioambiental), grant number: RTA2013-00053-C03-02". Diego F. Paladines-Quezada is the holder of an FPI fellowship from the Spanish Government. 


\begin{abstract}
Acknowledgments: The authors thank the "Oenological Station of Jumilla" for their partial support of this study. We thank José Cayetano Gómez-Martínez; Ana Cebrián-Pérez; David Martínez-Balsas; María Aseveración Palencia-Sigüenza; Juan Carlos Carcelén-Cutillas and Juan Corredor-Cano for field assistance and support in laboratory analyses.
\end{abstract}

Conflicts of Interest: The authors declare no conflict of interest.

\title{
References
}

1. Ochoa-Velasco, C.E.; Avila-Sosa, R.; Navarro-Cruz, A.R.; López-Malo, A.; Palou, E. Biotic and Abiotic Factors to Increase Bioactive Compounds in Fruits and Vegetables. In Food Bioconversion; Elsevier Science Publishing Co, Inc.: Amsterdam, The Netherlands, 2017; Volume 2, pp. 317-349, ISBN 9780128114131.

2. Portu, J.; López, R.; Santamaría, P.; Garde-Cerdán, T. Methyl jasmonate treatment to increase grape and wine phenolic content in Tempranillo and Graciano varieties during two growing seasons. Sci. Hortic. 2018, 240, 378-386. [CrossRef]

3. Jensen, J.S.; Demiray, S.; Egebo, M.; Meyer, A.S. Prediction of wine color attributes from the phenolic profiles of red grapes (Vitis vinifera). J. Agric. Food Chem. 2008, 56, 1105-1115. [CrossRef] [PubMed]

4. Crupi, P.; Alba, V.; Masi, G.; Caputo, A.R.; Tarricone, L. Effect of two exogenous plant growth regulators on the color and quality parameters of seedless table grape berries. Food Res. Int. 2019, 108667. [CrossRef] [PubMed]

5. Ruiz-García, Y.; Romero-Cascales, I.; Bautista-Ortín, A.B.; Gil-Muñoz, R.; Martínez-Cutillas, A.; Gómez-Plaza, E. Increasing bioactive phenolic compounds in grapes: Response of six Monastrell grape clones to benzothiadiazole and methyl jasmonate treatments. Am. J. Enol. Vitic. 2013, 64, 459-465. [CrossRef]

6. Garcia-Brugger, A.; Lamotte, O.; Vandelle, E.; Bourque, S.; Lecourieux, D.; Poinssot, B.; Wendehenne, D.; Pugin, A. Early signaling events induced by elicitors of plant defenses. Mol. Plant-Microbe Interact. 2006, 19, 711-724. [CrossRef]

7. $\mathrm{Wu}, \mathrm{J} . ;$ Lin, L. Elicitor-like effects of low-energy ultrasound on plant (Panax ginseng) cells: Induction of plant defense responses and secondary metabolite production. Appl. Microbiol. Biotechnol. 2002, 59, 51-57. [CrossRef] [PubMed]

8. Hammond-Kosack, K.E.; Jones, J.D.G. Resistance gene-dependent plant defense responses. Plant Cell 1996, 8, $1773-1791$. [CrossRef]

9. Zhao, J.; Davis, L.C.; Verpoorte, R. Elicitor signal transduction leading to production of plant secondary metabolites. Biotechnol. Adv. 2005, 23, 283-333. [CrossRef]

10. Radman, R.; Saez, T.; Bucke, C.; Keshavarz, T. Elicitation of plants and microbial cell systems. Biotechnol. Appl. Biochem. 2003, 37, 91. [CrossRef]

11. Gil-Muñoz, R.; Bautista-Ortín, A.B.; Ruiz-García, Y.; Fernández-Fernández, J.I.; Gómez-Plaza, E. Improving phenolic and chromatic characteristics of Monastrell, Merlot and Syrah wines by using methyl jasmonate and benzothiadiazole. J. Int. Sci. Vigne Vin. 2017, 51, 17-27. [CrossRef]

12. Ruiz-García, Y.; Gil-Muñoz, R.; López-Roca, J.M.; Martínez-Cutillas, A.; Romero-Cascales, I.; Gómez-Plaza, E. Increasing the phenolic compound content of grapes by preharvest application of abcisic acid and a combination of methyl jasmonate and benzothiadiazole. J. Agric. Food Chem. 2013, 61, 3978-3983. [CrossRef]

13. Ruiz-García, Y.; Romero-Cascales, I.; Gil-Muñoz, R.; Fernández-Fernández, J.I.; López-Roca, J.M.; Gómez-Plaza, E. Improving grape phenolic content and wine chromatic characteristics through the use of two different elicitors: Methyl jasmonate versus benzothiadiazole. J. Agric. Food Chem. 2012, 60, 1283-1290. [CrossRef]

14. Paladines-Quezada, D.F.; Moreno-Olivares, J.D.; Fernández-Fernández, J.I.; Bleda-Sánchez, J.A.; Martínez-Moreno, A.; Gil-Muñoz, R. Elicitors and pre-fermentative cold maceration: Effects on polyphenol concentration in Monastrell grapes and wines. Biomolecules 2019, 9, 671. [CrossRef] [PubMed]

15. Gil-Muñoz, R.; Fernández-Fernández, J.I.; Crespo-Villegas, O.; Garde-Cerdán, T. Elicitors used as a tool to increase stilbenes in grapes and wines. Food Res. Int. 2017, 98, 34-39. [CrossRef] [PubMed]

16. Gozzo, F. Systemic acquired resistance in crop protection: From nature to a chemical approach. J. Agric. Food Chem. 2003, 51, 4487-4503. [CrossRef] [PubMed]

17. Iriti, M.; Rossoni, M.; Borgo, M.; Faoro, F. Benzothiadiazole enhances resveratrol and anthocyanin biosynthesis in grapevine, meanwhile improving resistnce to Botrytis cinerea. J. Agric. Food Chem. 2004, 52, 4406-4413. [CrossRef]

18. Paladines-Quezada, D.F.; Fernández-Fernández, J.I.; Moreno-Olivares, J.D.; Bleda-Sánchez, J.A.; Gómez-Martínez, J.C.; Martínez-Jiménez, J.A.; Gil-Muñoz, R. Application of elicitors in two ripening periods of Vitis vinifera L. cv Monastrell: Influence on anthocyanin concentration of grapes and wines. Molecules 2021, 26, 1689. [CrossRef]

19. Pellerin, P.; Cabanis, J.C. Los glúcidos. In Enología: Fundamentos Científicos y Tecnológicos; Flanzy, C., Ed.; AMV Ediciones, Ediciones Mundi-Prensa: Madrid, Spain, 2000; pp. 66-96. ISBN 84-7114-859-5.

20. Doco, T.; Williams, P.; Pauly, M.; O’Neill, M.; Pellerin, P. Polysaccharides from grape berry cell walls. Part II. Structural characterization of the xyloglucan polysaccharides. Carbohydr. Polym. 2003, 53, 253-261. [CrossRef]

21. Hanlin, R.L.; Hrmova, M.; Harbertson, J.F.; Downey, M.O. Review: Condensed tannin and grape cell wall interactions and their impact on tannin extractability into wine. Aust. J. Grape Wine Res. 2010, 16, 173-188. [CrossRef]

22. SIAM Sistema de Información Agrario de Murcia. Available online: http:/ / siam.imida.es / apex/f?p=101:46:5540041647757103 (accessed on 20 December 2019). 
23. De Vries, J.A.; Rombouts, F.M.; Voragen, A.G.J.; Pilnik, W. Comparison of the structural features of apple and citrus pectic substances. Carbohydr. Polym. 1984, 4, 89-101. [CrossRef]

24. Apolinar-Valiente, R.; Romero-Cascales, I.; López-Roca, J.M.; Gómez-Plaza, E.; Ros-García, J.M. Application and comparison of four selected procedures for the isolation of cell-wall material from the skin of grapes cv. Monastrell. Anal. Chim. Acta 2010, 660, 206-210. [CrossRef] [PubMed]

25. Dubois, M.; Gilles, K.A.; Hamilton, J.K.; Rebers, P.A.; Smith, F. Colorimetric method for determination of sugars and related substances. Anal. Chem. 1956, 28, 350-356. [CrossRef]

26. Castro-López, L.; Gómez-Plaza, E.; Ortega-Regules, A.; Lozada, D.; Bautista-Ortín, A.B. Role of cell wall deconstructing enzymes in the proanthocyanidin-cell wall adsorption-desorption phenomena. Food Chem. 2016, 196, 526-532. [CrossRef] [PubMed]

27. Scott, R.W. Colorimetric determination of hexuronic acids in plant materials. Anal. Chem. 1979, 51, 936-941. [CrossRef]

28. Theander, O.; Aman, P. Studies on dietary-fibers. Analysis and chemical characterization of water-soluble and water-insoluble dietary-fibers. J. Agric. Res. 1979, 9, 97-106.

29. Rustioni, L.; Cola, G.; Maghradze, D.; Abashidze, E.; Argiriou, A.; Aroutiounian, R.; Brazão, J.; Chipashvili, R.; Cocco, M.; Cornea, V.; et al. Description of the Vitis vinifera L. Phenotypic variability in eno-carpological traits by a Euro-Asiatic collaborative network among ampelographic collections. Vitis J. Grapevine Res. 2019, 58, 37-46. [CrossRef]

30. Apolinar-Valiente, R.; Romero-Cascales, I.; Gómez-Plaza, E.; López-Roca, J.M.; Ros-García, J.M. The composition of cell walls from grape marcs is affected by grape origin and enological technique. Food Chem. 2015, 167, 370-377. [CrossRef]

31. Garrido-Bañuelos, G.; Buica, A.; Schückel, J.; Zietsman, A.J.J.; Willats, W.G.T.; Moore, J.P.; Du Toit, W.J. Investigating the relationship between grape cell wall polysaccharide composition and the extractability of phenolic compounds into Shiraz wines. Part I: Vintage and ripeness effects. Food Chem. 2019, 278, 36-46. [CrossRef]

32. Ortega-Regules, A.; Romero-Cascales, I.; Ros-García, J.M.; López-Roca, J.M.; Gómez-Plaza, E. A first approach towards the relationship between grape skin cell-wall composition and anthocyanin extractability. Anal. Chim. Acta 2006, 563, 26-32. [CrossRef]

33. Hernández-Hierro, J.M.; Quijada-Morín, N.; Martínez-Lapuente, L.; Guadalupe, Z.; Ayestarán, B.; Rivas-Gonzalo, J.C.; Escribano-Bailón, M.T. Relationship between skin cell wall composition and anthocyanin extractability of Vitis vinifera L. cv. Tempranillo at different grape ripeness degree. Food Chem. 2014, 146, 41-47. [CrossRef]

34. Revilla, G.; Zarra, I. Fisiología vegetal: Introducción a las células de las plantas: Membranas y pared. In Fundamentos de Fisiología Vegetal; Azcón-Bieto, J., Talón, M., Eds.; McGraw-Hill: Barcelona, Spain, 2003; pp. 3-22, ISBN 978-84-481-5168-3.

35. Apolinar-Valiente, R. Pared Celular de uva y Polisacáridos de Vinos de Distinta Procedencia, Elaborados Mediante Tecnologías Enzimáticas y de Frío. Ph.D. Thesis, Universidad de Murcia, Murcia, Spain, 2011.

36. Keegstra, K. Plant cell walls. Plant Physiol. 2010, 154, 483-486. [CrossRef] [PubMed]

37. John, M.; Röhring, H.; Schmidt, J.; Walden, R.; Schell, J. Cell signalling by oligosaccharides. Trends Plant Sci. 1997, 2, 111-115. [CrossRef]

38. Pellerin, P.; Doco, T.; Vidal, S.; Williams, P.; Brillouet, J.; O’Neill, M. Structural characterization of red wine rhamnogalacturonan II. Carbohydr. Res. 1996, 290, 183-197. [CrossRef]

39. Doco, T.; Brillouet, J.M.; Moutounet, M. Evolution of grape (Carignan noir cv.) and yeast polysaccharides during fermentation and post-maceration. Am. J. Enol. Vitic. 1996, 47, 108-110.

40. Vidal, S.; Francis, L.; Williams, P.; Kwiatkowski, M.; Gawel, R.; Cheynier, V.; Waters, E. The mouth-feel properties of polysaccharides and anthocyanins in a wine like medium. Food Chem. 2004, 85, 519-525. [CrossRef]

41. Vanholme, R.; Demedts, B.; Morreel, K.; Ralph, J.; Boerjan, W. Lignin biosynthesis and structure. Plant Physiol. 2010, 153, 895-905. [CrossRef]

42. Boerjan, W.; Ralph, J.; Baucher, M. Lignin biosynthesis. Annu. Rev. Plant Biol. 2003, 54, 519-546. [CrossRef]

43. Boudet, A.M. Lignins and lignification: Selected issues. Plant Physiol. Biochem. 2000, 38, 81-96. [CrossRef]

44. Mueller-Harvey, I.; Hartley, R.D.; Harris, P.J.; Curzon, E.H. Linkage of p-coumaroyl and feruloyl groups to cell-wall polysaccharides of barley straw. Carbohydr. Res. 1986, 148, 71-85. [CrossRef]

45. Showalter, A.M. Structure and function of plant cell wall proteins. Plant Cell 1993, 5, 9-23. [CrossRef]

46. Cassab, G.I.; Varner, J.E. Cell wall proteins. Annu. Rev. Plant Physiol. Plant Mol. Biol. 1988, 39, 321-353. [CrossRef]

47. Cosgrove, D. Paredes celulares: Estructura, biogénesis y expansión. In Fisiología Vegetal; Taiz, L., Zeiger, E., Eds.; Publicaciones de la Universitat Jaume I: Castelló de la Plana, Spain, 2006; Volume II, pp. 587-631, ISBN 978-84-8021-601-2.

48. Pinelo, M.; Arnous, A.; Meyer, A.S. Upgrading of grape skins: Significance of plant cell-wall structural components and extraction techniques for phenol release. Trends Food Sci. Technol. 2006, 17, 579-590. [CrossRef]

49. Lau, J.M.; McNeil, M.; Darvill, A.G.; Albersheim, P. Structure of the backbone of rhamnogalacturonan I, a pectic polysaccharide in the primary cell walls of plants. Carbohydr. Res. 1985, 137, 111-125. [CrossRef]

50. Ortega-Regules, A. Antocianos, Taninos y Composición de la Pared Celular en Distintas Variedades de uva. Evolución Durante la Maduración e Implicaciones Tecnológicas. Ph.D. Thesis, Universidad de Murcia, Murcia, Spain, 2006. 
51. Brisson, L.F.; Tenhaken, R.; Lamb, C. Function of oxidative cross-linking of cell wall structural proteins in plant disease resistance. Plant Cell 1994, 6, 1703-1712. [CrossRef]

52. Paladines-Quezada, D.F.; Moreno-Olivares, J.D.; Fernández-Fernández, J.I.; Bautista-Ortín, A.B.; Gil-Muñoz, R. Influence of methyl jasmonate and benzothiadiazole on the composition of grape skin cell walls and wines. Food Chem. 2019, 277, $691-697$. [CrossRef] 